\title{
Does abdominal diastasis influence lumbar pain during gestation?
}

\author{
A dimensão da diástase abdominal tem influência sobre a dor lombar durante a gestação? \\ Marília Duarte dos Santos ${ }^{1}$, Rafaela de Melo Silva ${ }^{1}$, Mariana Pereira Vicente ${ }^{2}$, Vanessa Pinho Palmezoni', Eliane Maria de \\ Carvalho', Ana Paula Magalhães Resende ${ }^{1,2}$
}

DOI 10.5935/1806-0013.20160011

\section{ABSTRACT}

BACKGROUND AND OBJECTIVES: To evaluate and compare the presence and size of recti abdominis diastasis in the second and third gestational trimester and to correlate them to lumbar pain incidence and intensity.

METHODS: This is a cross-sectional observational study with 128 pregnant women divided in two groups: 53 pregnant women in the second gestational trimester and 75 pregnant women in the third gestational trimester. Lumbar pain was evaluated with Roland Morris questionnaire and Pain Visual Analog Scale. Recti abdominis diastasis was measured with a caliper rule. Data were analyzed according to Spearman correlation and Mann-Whitney U test.

RESULTS: Comparison between groups has shown that pregnant women in the third gestational trimester had more recti abdominis diastasis, more reports of severe lumbar pain by the visual analog scale $(\mathrm{p}=0.0017)$ and further impact on daily life activities $(\mathrm{p}=0.0012)$. There has been positive correlation between recti abdominis diastasis size and scores obtained by Roland Morris questionnaire and visual analog scale.

CONCLUSION: Recti abdominis diastasis size, pain intensity and incapacity determined by low back pain were more severe in pregnant women in the third gestational trimester.

Keywords: Low back pain, Physiotherapy, Pregnant women, Quality of life, Rectus abdominis.

\section{RESUMO}

JUSTIFICATIVA E OBJETIVOS: Avaliar e comparar a ocorrência e dimensão da diástase dos músculos retos abdominais nos segundo e terceiro trimestres gestacionais e correlacioná-las com presença e intensidade da dor lombar.

\footnotetext{
1. Universidade Federal de Uberlândia, Faculdade de Medicina, Programa de Pós-Graduaçâo em Ciências da Saúde, Uberlândia, MG, Brasil.

2. Universidade Federal de Uberlândia, Faculdade de Educação Física e Fisioterapia, Curso de Fisioterapia, Uberlândia, MG, Brasil.

Submitted in December 04, 2015.

Accepted for publication in February 02, 2016.

Conflict of interests: none - Sponsoring sources: none.

Correspondence to:

Ana Paula Magalhães Resende

Rua Benjamin Constant, 1286 - Bairro Nossa Senhora Aparecida

38400-678 Uberlândia, MG, Brasil.

E-mail: anapaulamrb@gmail.com

(C) Sociedade Brasileira para o Estudo da Dor
}

MÉTODOS: Estudo observacional do tipo transversal com 128 gestantes, divididas em dois grupos: 53 gestantes no segundo trimestre gestacional e 75 gestantes no terceiro trimestre gestacional. Utilizou-se para avaliar a dor lombar o questionário Roland Morris e a escala analógica visual da dor. A mensuração da diástase dos músculos retos abdominais foi realizada com auxílio de um paquímetro. Os dados foram analisados segundo a correlação de Spearman e teste U de Mann-Whitney.

RESULTADOS: A comparaçáo dos grupos demonstrou que as gestantes do terceiro trimestre apresentavam maior diástase abdominal, mais relatos de dor lombar intensa por meio da escala analógica visual $\mathrm{p}=0,0017$ e maior impacto nas atividades da vida diária $(\mathrm{p}=0,0012)$. A correlação foi positiva entre a dimensão da diástase dos músculos retos abdominais e os escores obtidos no questionário Roland Morris e na escala analógica visual.

CONCLUSÃO: A dimensão da diástase dos músculos retos abdominais, a intensidade da dor e a incapacidade determinadas pela lombalgia foram maiores nas gestantes do terceiro trimestre gestacional.

Descritores: Dor lombar, Fisioterapia, Gestantes, Qualidade de vida, Reto do abdômen.

\section{INTRODUCTION}

Women go through hormonal and biochemical changes during gestation ${ }^{1}$. Uterus in constant growth due to increased fetal size protrudes the abdomen and favors anterior gravity center displacement ${ }^{2}$. These changes progressively increase lumbar and thoracic curvature and pelvic anteversion, generating muscle overload and consequently pain ${ }^{1,2}$.

Low back pain is certainly the most common complaint during gestation $^{1,3}$. Its presence is attributed to sacroiliac and intervertebral joints relaxation and increased levels of progesterone, estrogen and relaxin (responsible for favoring ligament laxity $)^{1,4}$. Hypermobility of such joints generates joint instability and consequent overload on stabilizing ligaments and muscles which, associated to increased weight, determine musculoskeletal system overload, pull the spine anteriorly and determine low back pain ${ }^{1,3,4}$.

In non-pregnant women, lumbo-pelvic instability is a relevant factor for the genesis of low back pain, because musculoskeletal system unbalance leads to lack of dynamic stability and consequent overload of musculoskeletal structures ${ }^{5}$. Abdominal muscles are major stabilizers so the weaker these muscles, the more severe will be the joint instability and consequently more severe low back pain ${ }^{5,6}$.

During gestation, recti abdomini muscles borders separa- 
te to allow fetal growth ${ }^{2,7-9}$. This is called rectus abdomini muscles diastasis (RAMD) and is associated to stretching and weakening of such muscles ${ }^{2,7-9}$. Some authors consider excessive or pathological a gap larger than $3 \mathrm{~cm}^{7,8}$. However, literature is controversial with regard to RAMD reference value, that is, when to consider it pathological and whether the classification should be used only during the puerperal period or also during gestation ${ }^{8}$. Pathological RAMD increases risks for developing future abdominal hernia and impairs the return of such muscles to their pre-gestational anatomic position ${ }^{2,8,9}$.

Notwithstanding low back pain being multifactorial ${ }^{1,4}$, the relationship between the size of RAMD gap and low back pain presence and intensity has not yet been described.

This study aimed at evaluating the presence of RAMD in the second and third gestational trimesters and at correlating it with low back pain presence and intensity.

\section{METHODS}

This is a prospective, observational cross-sectional study carried out from January 2013 to April 2015 with pregnant women assisted in public pre-natal services of the city of Uberlândia-MG.

Convenience sample was made up of 128 volunteer pregnant women. Inclusion criteria were physiological gestation, single live fetus without malformation, and exclusion criteria were pregnant women with chronic-degenerative diseases, high risk gestation or twin gestation. All participants have signed the Free and Informed Consent Term (FICT). Patients were divided in two groups: Group 2T in the second gestational trimester and Group $3 \mathrm{~T}$ in the third gestational trimester. Second gestational trimester was considered the period between the $14^{\text {th }}$ and $27^{\text {th }}$ week and third trimester as from the $28^{\text {th }}$ week ${ }^{10}$.

Socio-demographic data, personal and clinical history, current gestation, previous gestations and delivery data were collected initially. Visual analog scale (VAS) from zero to 10 was applied to patients with low back pain. Pain was considered mild when VAS between 1 and 3; moderate between 4 and 6 and severe between 7 and 10. Then, Roland Morris questionnaire was applied to quantify low back pain-induced incapacity. Finally, RAMD was evaluated with the aid of a caliper rule, to quantify the separation of rectus abdomini muscles bundles along the linea alba in umbilical, supraumbilical and infraumbilical regions.

RAMD was measured with patients in the supine position, hips and knees flexed to $90^{\circ}$, feet flat on the stretcher and upper limbs extended along the body. Three points were marked on the abdomen with dermatographic pencil and with the aid of a tape-measure: one point on the umbilical cicatrix, one point $4.5 \mathrm{~cm}$ above, considered supraumbilical, and one point $4.5 \mathrm{~cm}$ below, considered infraumbilical ${ }^{11}$. Then we requested trunk flexion until the lower scapula angle was outside the stretcher. In this position, the evaluator palpated medial borders of rectus abdomini muscles and measured with the caliper rule the distance on the three marked regions.

Data were collected by two adequately trained researchers by the investigator in charge.

A universal caliper rule, which accurately measures the distance between two points, was used to evaluate diastasis. Measurement scale of the caliper rule's mobile cursor allows decimal reading precision by the alignment of such scale with the measurement of the ruler.

VAS was used to evaluate low back pain and Roland Morris questionnaire was applied to evaluate low back pain-induced functional incapacity and indirectly patients' quality of life. This self-applicable questionnaire is made up of 24 closed questions (yes or no), related to daily activities, pain and function. For each affirmative question 1 point is considered. Final score is determined by the sum of values with minimum and maximum of " 0 " and " 24 ", respectively"

\section{Statistical analysis}

Central trend (mean), dispersion (standard deviation), frequency and percentage were measured for data descriptive analysis. Additionally, Spearman's Correlation Coefficient was applied to check the presence or not of statistically significant correlations; Mann-Whitney $U$ test was applied to check the presence or not of statistically significant differences between the two groups. Significance level was 5\% in a bilateral test in all analyses.

This study was approved by the Research Ethics Committee, Universidade Federal de Uberlândia, under protocol $145.623 / 2012$ and was developed according to guidelines of Resolution 466/12, National Health Council.

\section{RESULTS}

Participated in the study 129 pregnant women but the final sample was $128,53(41.4 \%)$ in the second trimester and 75 $(58.6 \%)$ in the third gestational trimester. There has been a waiver due to discomfort in the supine position at evaluation date.

Patients of both groups had similar ages, with mean of $26.5 \pm 6.1$ years for group $2 \mathrm{~T}$ and $27 \pm 5.3$ years for group $3 \mathrm{~T}$ ( $\mathrm{p}=1.0000$, Mann-Whitney test).

When comparing groups with regard to RAMD and presence of low back pain, group $3 \mathrm{~T}$ patients had higher values, as shown in table 1.

Table 1. Comparison between groups with regard to abdominal diastasis size, visual analog scale and Roland Morris questionnaire score

\begin{tabular}{lccc}
\hline Variables & $\begin{array}{c}\text { Group 2T } \\
\text { Mean } \pm \text { SD }\end{array}$ & $\begin{array}{c}\text { Group 3T } \\
\text { Mean } \pm \text { SD }\end{array}$ & p value \\
\hline Supraumbilical diastasis & $3(1.9)$ & $5.1(3.1)$ & $0.0000^{*}$ \\
Umbilical diastasis & $3.6(2.3)$ & $5.7(3.3)$ & $0.0000^{*}$ \\
Infraumbilical diastasis & $3(2.6)$ & $4.8(3.6)$ & $0.0001^{*}$ \\
Roland Morris score & $2(5.1)$ & $5(5.3)$ & $0.0012^{*}$ \\
Visual analog scale & $3(2.8)$ & $5( \pm 3.1)$ & $0.0017^{\star}$ \\
${ }^{*} \mathrm{p}<0.05 \cdot \mathrm{SD}=$ standard deviation; Differences detected by Mann-Whitney U test.
\end{tabular}


Low back pain was evaluated by VAS. In our study, 33 (25\%) patients have reported not having low back pain. Remaining participants, or $74 \%$, have stated having low back pain of different intensities.

Tests were applied to check possible correlations between RAMD size and final Roland Morris score. Results have shown low, positive and significant correlation $(0.20<\mathrm{R}<0.39)$. Patients with larger RAMD had higher final questionnaire scores, as shown in table 2.

Table 2. Correlation between Roland Morris questionnaire score and abdominal diastasis size in the three regions

\begin{tabular}{lcl}
\hline Variables $(\mathrm{n}=128)$ & Roland Morris & $\mathrm{p}$ value \\
\hline Supraumbilical diastasis & 0.2209 & $0.012^{*}$ \\
Umbilical diastasis & 0.2375 & $0.008^{*}$ \\
Infraumbilical diastasis & 0.2318 & $0.008^{*}$ \\
\hline
\end{tabular}

Values obtained by means of Spearman's Rank Correlation Coefficient; ${ }^{*} p<0.05$.

When correlating RAMD values and VAS there has been weak, positive and significant correlation $(0.20<\mathrm{R}<0.39)$. Patients with larger RAMD had higher VAS values, as shown in table 3.

Table 3. Correlation between visual analog scale and abdominal diastasis size in the three evaluated regions

\begin{tabular}{lcc}
\hline Variables $(\mathrm{n}=128)$ & VAS & $\mathrm{p}$ value \\
\hline Supraumbilical diastasis & 0.2540 & $0.004^{*}$ \\
Umbilical diastasis & 0.2954 & $0.001^{*}$ \\
Infraumbilical diastasis & 0.3025 & $0.001^{*}$ \\
\hline
\end{tabular}

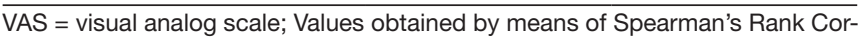
relation Coefficient; ${ }^{*} p<0.05$.

\section{DISCUSSION}

This study has shown that RAMD size is larger in patients in the third gestational trimester as compared to the second trimester, which was foreseeable due to larger uterus and the larger gap between rectus abdomini muscles bundles to accommodate such volume9. Low back pain is defined as pain located in the lower dorsal region, in area located between the gluteus fold and the last costal $\operatorname{arch}^{13}$. It is a common complaint among pregnant women, especially during the third gestational trimester ${ }^{14}$. Our study has observed that gestational low back pain was present in $74 \%$ of studied women, which is in line with Brazilian literature data, where percentage varies from 45 to $83 \%^{15,16}$. In a recent study, Fernandes da Mota et al. ${ }^{17}$ have submitted 84 women to ultrasound and have considered presence of RAMD when the distance between rectus abdominis muscles was larger than $16 \mathrm{~mm}$. They have also evaluated low back pain by asking patients to point in a figure the painful area and to classify pain as moderate to severe. Women with larger diastasis had not necessarily more low back pain, and these results are opposed to those found in our study. However, just 23 out of 84 included women have referred low back pain, and the small sample could be a determinant factor for the lack of correlation.
The prevalence of low back pain during gestation has varied from 20 to $90 \%$ in different studies ${ }^{1,18}$ and could influence the ability to sit, walk, stand up, in addition to decreasing women's ability to perform daily life activities ${ }^{19-22}$. Our study has evaluated low back pain by means of VAS, which is broadly described in the literature and is used to evaluate different types of pain ${ }^{23,24}$.

Mean low back pain scores for both groups was $4 \pm 5.3$, according to Roland Morris questionnaire ${ }^{12}$, showing that although with pain, pregnant women have not considered it disabling (disabling $=$ score $>14)^{12}$. In a recent study, Madeira et al. ${ }^{25}$ have evaluated low back pain-induced incapacity in 296 pregnant women by means of the Roland Morris questionnaire and have found means similar to our study data. From 185 painful pregnant women, 116 had scores below 5 in this same questionnaire ${ }^{25}$.

On the other hand, RAMD is present in 30 to $70 \%$ of pregnant women ${ }^{26}$. Evaluation methods found in the literature were: palpation ${ }^{27,28}$, caliper rule $^{29,30}$ and ultrasound ${ }^{31,32}$. Our study has used the caliper rule to measure RAMD size. In addition to being accurate and of low cost, this method has been used in numerous other studies ${ }^{6,9}$. The reproducibility of bidimensional ultrasound was recently tested to evaluate the distance between two rectus abdomini muscles bundles ${ }^{30}$. Results have shown high reproducibility and authors have suggested this method as ideal to evaluate diastasis size $^{31}$; however, its access is limited since the high-cost equipment is not always available and professionals are not always qualified for this type of evaluation. This same research team has tested inter and intra-observers reproducibility to evaluate diastasis size with finger widths ${ }^{31}$ and have found a moderate agreement among evaluators ( $\mathrm{wK}=0.534$ ) classifying gap dimension as $0.5 ; 1 ; 1.5$ and 2 fingers.

Our study has carried out evaluations in different care units for risk pregnant women of the city of Uberlândia, and caliper rule was selected for its cost, reproducibility and easy transportation. Intra-observer reproducibility of the caliper rule is high and authors have concluded that it is a reliable tool to evaluate rectus abdomini muscles ${ }^{28}$. Highest RAMD values found in our study were in the umbilical region, with mean of $3.6 \pm 2.3 \mathrm{~cm}$ for the second trimester and of $5.7 \pm 3.3 \mathrm{~cm}$ for the third trimester. Chiarello et al. ${ }^{11}$ have evaluated RAMD during gestation with a method similar to our study and have found slightly higher values for the infraumbilical region $(6.4 \mathrm{~cm})$ as compared to the umbilical region $(6 \mathrm{~cm})$. However, both studies are similar when umbilical region RAMD values are compared. This study has shown that pregnant women with larger rectus abdomini muscles gap have referred higher low back pain intensity in the second and third trimesters. A previous study ${ }^{11}$ has evaluated the effects of abdominal strengthening on the presence and size of RAMD in pregnant women and has found that pregnant women submitted to clinical intervention had lower abdominal diastasis values. 


\section{CONCLUSION}

This study stands out for the number of included pregnant women and the unprecedented correlation between low back pain and abdominal diastasis size during gestation. However, we believe that evaluation of low back pain before gestation and of different abdominal muscles would expand and enrich our data. Evaluating and correlating these two outcomes in the puerperal period are suggestions of researchers for further studies in this research line. Based on our results, we recommend the evaluation of diastasis during gestation for early intervention, to decrease rectus abdominal muscles gap and possibly low back pain-induced discomfort.

\section{REFERÊNCIAS}

1. Bishop A, Holden MA, Ogollah RO, Foster NE. Current management of pregnancy-related low back pain: a national cross-sectional survey of UK physiotherapists. Physiotherapy. 2015;19(S0031-9406(15):03771-2. [Epub ahead of print]

2. Novaes FS, Shimo AK, Lopes MH. [Low back pain during gestation]. Rev Lat Am Enfermagem. 2006;14(4):620-4. Portuguese.

3. Gomes MR, Araújo RC, Lima AS, Pitangui AC. Lombalgia gestacional: prevalência e características clínicas em um grupo de gestantes. Rev Dor. 2013;14(2):114-7.

4. Pereira NT, Ferreira LA, Pereira WM. Efetividade de exercícios de estabilizaçáo segmentar sobre a dor lombar crônica mecânico-postural. Fisioter Mov. 2010;23(4):605-14

5. Graup S, de Araújo Bergmann ML, Bergmann GG. Prevalence of nonspecific lumbar pain and associated factors among adolescents in Uruguaiana, state of Rio Grande do Sul. Rev Bras Ortop. 2014;49(6):661-7.

6. Rett MT, Araújo FR, Rocha I, Silva RA. Diástase dos músculos retoabdominais no puerpério imediato de primíparas e multíparas após o parto vaginal. Fisioter Pesq. 2012;19(3):236-41.

7. Rett MT, Braga MD, Bernandes NO, Andrade SC. Prevalência de diástase dos músculos retoabdominais no puerpério imediato: comparação entre primíparas e multíparas. Rev Bras Fisioter. 2009;13(4):275-80.

8. Akram J, Matzen SH. Rectus abdominis diastasis. J Plast Surg Hand Surg. 2014;48(3):163-9.

9. Leite AC, Araújo KK. Diástase dos retos abdominais em puérperas e sua relação com variáveis obstétricas. Fisioter Mov. 2012;25(2):389-97.

10. Brasil. Ministério da Saúde. [Internet]. Assistência pré-natal: manual técnico. Brasília (DF): Ministério da Saúde; 2000 [citado 2015 Março 9]. Disponível em: <http:// bvsms.saude.gov.br/bvs/publicacoes/cd04_11.pdfs.

11. Chiarello CM, Falzone LA, McCaslin KE, Patel MN, Ulery KR. The effects of an exercise program on diastasis recti abdominis in pregnant women. J Women's Health
Phys Ther. 2005;29(1):11-6.

12. Nusbaum L, Natour J, Ferraz MB, Goldenberg J. Translation, adaptation and validation of the Roland-Morris questionnaire--Brazil Roland-Morris. Braz J Med Biol Res. 2001;34(2):203-10.

13. Ferreira CH, Nakano AM. [Coceptual bases supporting the obtention of knowledge about back pain in pregnancy]. Rev Lat Am Enfermagem. 2001;9(3):95-100. Portuguese.

14. Barbosa CM, Silva JM, Moura AB. Correlaçấo entre o ganho de peso e a intensidade da dor lombar em gestantes. Rev Dor. 2011;12(3):205-8.

15. Santos MM, Gallo AP. Lombalgia gestacional: prevalência e características de um programa pré-natal. Arq Bras Ciên Saúde. 2010;35(3):174-9.

16. Martins RF, Silva JL. [Back pain is a major problem for many pregnant women]. Rev Assoc Med Bras. 2005;51(3):144-7. Portuguese.

17. Fernandes da Mota PG, Pascoal AG, Carita AI, Bø K. Prevalence and risk factors of diastasis recti abdominis from late pregnancy to 6 months postpartum, and relationship with lumbo-pelvic pain. Man Ther. 2015;20(1):200-5.

18. Han IH. Pregnancy and spinal problems. Curr Opin Obstet Gynecol. 2010;22(6):477-81

19. Ostgaard HC, Andersson GB, Karlsson K. Prevalence of back pain in pregnancy. Spine (Phila Pa 1976). 1991;16(5):549-52.

20. Ostgaard HC, Zetherström G, Roos-Hansson E. Back pain in relation to pregnancy: a 6-year follow-up. Spine (Phila Pa 1976). 1997;22(24):2945-50.

21. Rodrigues WF, Silva LR, Nascimento MA, Pernambuco CS, Giani TS, Dantas EH Prevalence of lower back pain and physical inactivity: the impact of psychosocial factors in pregnant women served by the Family Health Strategy. Einstein. 2011;9(4 Pt 1):489-93.

22. Cortez PJ, Franco TA, Sene TM, Carvalho TD, Tomazini JE. Correlaçáo entre a dor lombar e as alteraçōes posturais em gestantes. Arq Bras Ciênc Saúde. 2012;37(1):30-5.

23. Rostami M, Noormohammadpour P, Mansournia MA, Hantoushzadeh S, Farahbakhsh F, Nourian R, et al. Comparison of the thickness of lateral abdominal muscles between pregnant women with and without low back pain. PM R. 2015;7(5):474-8.

24. Korelo RI, Ragasson CA, Lerner CE, de Morais JC, Cossa JB, Krauczuk C. Efeito de um programa cinesioterapêutico de grupo, aliado à escola de postura, na lombalgia crônica. Fisioter Mov. 2013;26(2):389-94.

25. Madeira HG, Garcia JB, Lima MV, Serra HO. [Disability and factors associated with gestational low back pain]. Rev Bras Ginecol Obstet. 2013;35(12):541-8. Portuguese.

26. Boissonnault JS, Blaschak MJ. Incidence of diastasis recti abdominis during the childbearing year. Phys Ther. 1988;68(7):1082-6.

27. Bursch SG. Interrater reliability of diastasis recti abdominis measurement. Phys Ther. 1987;67(7):1077-9.

28. Boxer S, Jones S. Intra-rater reliability of rectus abdominis diastasis measurement using dial calipers. Aust J Physiother. 1997;43(2):109-14.

29. Hsia M, Jones $S$. Natural resolution of rectus abdominis diastasis. Two single case studies. Aust J Physiother. 2000;46(4):301-7.

30. Mota P, Pascoal AG, Sancho F, Bø K. Test-retest and intrarater reliability of 2- dimensional ultrasound measurements of distance between rectus abdominis in women. J Orthop Sports Phys Ther. 2012;42(11):940-6.

31. Mota P, Pascoal AG, Sancho F, Carita AI, Bø K. Reliability of the inter-rectus distance measured by palpation. Comparison of palpation and ultrasound measurements. Man Ther. 2013;18(4):294-8. 